\title{
Groundwater Market and Agricultural Development in West Bengal: Perspectives from a Village Study
}

\author{
Koichi Fujita, ${ }^{*}$ Ashok Kundu $^{\dagger}$ and W. M. H. Jaim ${ }^{\ddagger}$
}

\begin{abstract}
Based on intensive village study this paper tries to show that the rapid agricultural growth in West Bengal since the 1980s is mainly attributable to the development of private shallow tubewell irrigation, rather than the agrarian reforms. Large farmers mainly invested in tubewells, but it does not mean that they monopolize agricultural profit as the so-called 'waterlords'. On the contrary, water sales business became less profitable as the number of tubewells increased in the village, and the real water charge declined through the changes of contractual arrangement in the groundwater market. It also comments on the current situation of irrigation subsidy relating to state-operated DTWs and power subsidy given to electrified tubewells, as well as their effects to irrigated farming. Lastly, it points out the large difference in factor shares in rice production between West Bengal and Bangladesh, arguing that West Bengal agriculture is much more equitable in favor of landless laborers.
\end{abstract}

Key words: tubewell irrigation, West Bengal, competition, factor share, subsidy, agrarian reforms.

\section{Introduction}

The 'Green Revolution' since the mid-1960s in India was characterized as both region- and commodity-specific; i.e. it concentrated in northern India regions such as Punjab, Haryana, and the western part of Uttar

\footnotetext{
* Kyoto University.

†alyani University, India.

$\ddagger$ Bangladesh Agricultural University, Bangladesh. The authors would like to extend sincere gratitude to Dr. Sudhin K. Mukhopadhyay, Reader in Economics, Rishi Bankim Chandra Evening College and Faculty Associate, Institute of Study on Population, Agriculture, and Rural Change (INSPARC), University of Kalyani, West Bengal, India, for his patient guidance and suggestions during our research and also for his valuable comments on to the draft paper. Special appreciation is also extended to Dr. Bhaswar Moitra, Reader, Economics Department, Jadavpur University, Kolkata for his kind and valuable comments on our draft paper. Last, and not least, we appreciate Mr. Toshihiko Suda, researcher of Research Institute of Norin Chukin Bank, Japan very much for his full cooperation with our survey in the village and useful suggestions and insights provided to us.
}

Pradesh and it was basically a "wheat revolution'. This fact was a basic reason why India failed to eradicate mass poverty until the end of the 1970s although food self-sufficiency in terms of no cereal import was achieved due to the success of the 'Green Revolution' strategy. However, since the inception of the 1980s agriculture in India started to record a high growth rate in almost all regions and for most commodities for more than a decade,") which along with the development of nonagricultural sectors contributed to its overall rural development and alleviation of rural poverty. Most noteworthy was that the poorest and the most backward regions of eastern India also experienced a rapid agricultural and rural development since the 1980s. West Bengal was not the exception to this wave of drastic transformation.

Groundwater irrigation played a vital role in leading the 'Green Revolution' in India and also in its eastern state of West Bengal. In spite of stagnation for a long period and J. K. Boyce's pessimistic projections (Boyce [2]), rice production in West Bengal started to record a rapid increase from the early 1980s (Saha and Swaminathan [15]), most probably 
because of the rapid diffusion of private shallow tubewells and the related expansion of dry-season paddy (boro) areas with high-yielding varieties and agro-chemicals, although the increase of the yield of monsoon-season paddy (aman) also contributed to it. The contribution of irrigated boro paddy area expansion to overall rice sector grow th became more and more evident and important in recent years. This rice sector growth sustained until today and the more recent development of non-rice sectors such as oilseeds, horticulture, and aquaculture brought about a drastic change in rural economy and raised the living standard of its population to a substantial degree (Gazdar and Sengupta [9]). However, despite its importance, the contribution of technological change in agriculture induced by the development of groundwater irrigation has not been properly appreciated, and academic arguments still seem to accord major credit to agrarian reforms in West Bengal, including redistribution of land, tenancy reforms (such as Operation Barga, a famous registration programme of sharecroppers), and panchayat reforms. ${ }^{2)}$

An important factor that impedes objective assessment of the contribution of groundwater irrigation to agricultural growth in West Bengal is the scarcity of statistical data on private tubewells. In particular, data are lacking on the regional distribution of private tubewells and its changes over time. This is a major constraint hindering any rigorous economic analysis of the rapid agricultural grow th in the state since the $1980 \mathrm{~s}^{3}$.

Micro-level intensive studies on groundwater irrigation are also far from abundant, and unfortunately the very few studies that are available are weak in both data set obtained and analytical depth. For example, based on his study in a village in Bardhaman district in 1991, Webster correctly pointed out that "it is the dry season boro paddy cultivation enabled by shallow tubewells which has been the real base for the rapid growth in foodgrain production in the district in the 1980s and early 1990s" (Webster [19], p. 336) but found a skewed distribution of private shallow tubewells in favor of large farmers, and rushed to conclude that the high returns to boro paddy cultivation are secured by the tubewell owners, without sufficient economic analysis of the village-level groundwater market.) In West Bengal, there is virtually no study so far that clarifies how the groundwater market actually functions in a systematic manner, based on analysis of profitability of shallow tubewell investment and groundwater-irrigated (boro paddy) farming.)

The major purpose of this paper is not to refute the general understanding that agrarian reforms are the main cause of the agricultural growth since the 1980s in West Bengal, but in stead, it tries to shed light on the critical role played by the private shallow tubewell investment by large farmers in the agricultural development. In addition, it pays full attention to the neglected aspects of the evolution and the structure of village-level groundwater markets, and through the analysis it tries to reveal a more complete picture of the dynamics of agricultural change in West Bengal.

Due mainly to the lack of semi-macro level data already mentioned, this paper focuses on only a selected village in Nadia district in West Bengal, where an intensive field survey was conducted in September 2000 after a preliminary study in November 1999. Despite apparent limitations due to this methodology adopted, this study tries to cover several criti$\mathrm{cal}$ and wider issues and points.

First, it tries to delineate, as much as possible, the historical process of irrigation development and agricultural change in the study village from the mid-1960s until today. Besides showing that the agricultural development in the village is mainly attributable to the private shallow tubewell investment by large farmers, it attempts to show how the state-level policy changes affected the development of irrigated farming on the one hand, and how the groundwater market experienced a structural change over time on the other hand. Second, through rigorous economic analysis it tries to question the existence of 'waterlords' who secure high returns from boro paddy cultivation. It shows how groundwater markets became more and more competitive due to the increase of shallow tubewells in confined areas, which caused a declining rate of return to such investment. In addition, while it shows how groundwater markets function relatively well at the village level, at the same time it points out when and how such markets fail and why. Third, as a byproduct of analysis, the large difference in 
factor shares (especially land and labor) in rice production between West Bengal and Bangladesh will be pointed out and discussed. The comparison between the two regions with similar agro-ecological conditions and historical background is meaningful and can provide important implications. Fourth, in the minor irrigation sector in West Bengal, the more than 30-year-old system of state-operated deep tubewells is still working and this study presents a preliminary discussion on its current status and future prospects. Fifth, it tries to evaluate the effects of power subsidy on the minor irrigation sector, and examines the question of who the beneficiaries of the subsidy are. Lastly, the paper shows how farmers have been so far coping with the problem of declining groundwater level and discusses its implications for both sustainability and efficiency of groundwater markets.

The composition of this paper is as follows. In Section 2, after introducing the outline of the study village, the process of development of groundwater irrigation and irrigated farming is presented, based on results of interviews with several village key informants as well as the data from the local office of Minor Irrigation Department in West Bengal. In Section 3, based on a direct interview survey of all the shallow tubewell owners in the village, economic analysis of tubewell investment is conducted and presented. In Section 4, we turn to the economic analysis of irrigated farming from the viewpoint of water buyers, mainly that of boro paddy cultivation. In Section 5, some critical factors affecting the structure of the groundwater market are pointed out and discussed. The issue of the state-operated deep tubewells and the power subsidy are the key topics. Finally, major findings and implications are summarized in Section 6.

\section{Process of Changes in Irrigation and Agriculture}

The name of the study village is Gotera, which belongs to Chakuda C. D. Block, Nadia district. It is about an hour's journey by road to the northeast from the town Kalyani, which is located north of Kolkata about two to three hours by car.

The eastern and southern edges of West Bengal from Murshidabad to Midnapore, through Nadia, Hoogly, Howrah, 24-Parganas
(North) and 24-Parganas (South) are the major groundwater irrigation development belt and Nadia district is the nuclear area among others. The average annual rainfall in Nadia district reaches to $1,474 \mathrm{~mm}$ and $88 \%$ of it is concentrated in the monsoon season from May to October. Aman (monsoon-season paddy) can be grown basically in the rainfed condition but boro (dry-season paddy) cultivation is not possible without irrigation. Another notable feature of Nadia district is that it is one of the most backward areas in terms of land reform policy implementation; i.e. redistributed land in the district at the end of September 1999 (accumulated) is only 7,800 hectares $(0.03 \%$ of farm land) while the same figure for the whole West Bengal is 426 thousand hectares (7.5\%). It should also be noted that in the study village almost no land reform measures were implemented, not even Operation Barga.

According to the Population Census of 1991 there were 253 households (1,327 persons) living in the 642 -acre territory of the village. By November 1999 when a preliminary survey was conducted, almost $100 \%$ of the farmland was under irrigation, and the major cropping pattern was double cropping of rice (aman followed by boro), but in a relatively elevated area, though small in acreage, farmers were growing some horticultural crops, e.g., vegetables, bananas, etc.

At the time of the main survey in September 2000 there were two state-operated deep tubewells (hereinafter referred to as DTW) and 31 private shallow tubewells (hereinafter referred to as STW) in the village. STWs can be classified into three types; i.e. diesel-operated STW, electricity-operated STW, and submergible STW (in this paper hereinafter referred to as SM, which Webster [19] called MSTW, an abbreviation of mini-submergible tubewells). There were in total 3 diesel STWs, 18 electric STWs, and 10 SMs. SM is electricity-operated and its motor is buried 60 feet below the ground. It is sometimes called mini-DTW by the villagers because it exploits the groundwater $180-200$ feet below, which lies between the 60-70 feet deep water tapped by STWs (both diesel and electric) and that at 400 feet utilized by DTWs.

Based on information obtained from several village informants and from the local office of 
the Minor Irrigation Department of the State Government, a brief history of irrigation development and agricultural change in the village can be presented as below.

\section{1) Mid-1960s to mid-1970s}

The construction of two DTWs was completed in April 1964. ${ }^{6)}$ Both were electricityoperated and the lifted groundwater was distributed through a network of underground pipes. It means that the command area of each DTW was technically fixed. These DTWs have been operated directly by the West Bengal State Government until today. One operator and two assistants were officially nominated for each DTW. All the operation and maintenance costs, including operator's (and assistants') salary, spare parts, electricity charges, etc., have been borne by the State. Farmers only paid a fixed amount of highly subsidized water charge on a per acre basis. For the task of problem solving and necessary coordination, a beneficiary committee was organized for each DTW, comprised of some key persons such as the local official of the Minor Irrigation Department, the chairman (and/or members) of gram panchayat office, operator, and a few representatives of beneficiary farmers.

The total command area irrigated by the two DTWs was approximately 150 acres, and has not changed much until today. It means that about $17 \%$ of the village farmland was irrigated by the public sector. At that time there was also some small-scale tank irrigation, but it was very limited. Thus during the mid-1960s through the mid-1970s most of the village farmland was single cropped with aman paddy in the monsoon season, while in the dry season being left fallow or sown with some lowproductive pulses like khesari (grass pea). Boro cultivation was limited to the relatively narrow irrigated areas.

\section{2) Mid-1970s to mid-1980s}

In this period some changes took place with the introduction of diesel STWs. Tank irrigation also expanded to some extent because the diesel engines (of STWs) were also utilized for lifting tank water. A village informant estimated that the ratio of irrigated farmland in the village increased to $50-60 \%$ by the mid1980 s, although another informant's estimate was more conservative. In any case, cropped area of boro paddy expanded gradually as private diesel STWs spread in this period. One
Table 1. Diffusion of tubewells in the study village

\begin{tabular}{|c|c|c|c|}
\hline & Diesel STW & Electric STW & $\mathrm{SM}$ \\
\hline 1982 & 2 & & \\
\hline 83 & 4 & & \\
\hline 84 & 1 & 2 & \\
\hline 85 & 1 & 1 & \\
\hline 86 & 1 & 2 & \\
\hline 87 & & 6 & \\
\hline 88 & & 4 & \\
\hline 89 & & 2 & \\
\hline \multicolumn{4}{|l|}{90} \\
\hline \multicolumn{4}{|l|}{91} \\
\hline 92 & & 1 & 2 \\
\hline 93 & 1 & & \\
\hline 94 & 1 & & \\
\hline 95 & & & 3 \\
\hline 96 & & 2 & 2 \\
\hline 97 & & & 2 \\
\hline \multicolumn{4}{|l|}{98} \\
\hline \multicolumn{4}{|l|}{99} \\
\hline \multicolumn{4}{|l|}{2000} \\
\hline $\begin{array}{l}\text { Total } \\
\text { (Current } \\
\text { number) }\end{array}$ & 3 & 13 & 9 \\
\hline
\end{tabular}

Source: Field survey in September 2000.

notable fact is that at that time farmers did not purchase irrigation water from STW owners, but the latter rented land seasonally from the former for growing boro paddy. Rent for the land was paid mostly in kind; i.e. 3 maunds (one maund $=37.3 \mathrm{~kg}$ ) of paddy per bigha (one bigha $=1 / 3$ acres) of land.

\section{3) Mid-1980s to mid-1990s}

West Bengal experienced a poor harvest of rice for two succeeding years at the beginning of the 1980s due to severe drought. Various policies and programs were planned and implemented by the State Government for increasing rice production. In particular, it promoted enthusiastically the electrification of STWs through the 'cluster' system, under which at least six STWs were introduced (or converted from diesel STW) in a block of area called a 'cluster'. The wave of such rural electrification reached to the study village also and many electric STWs were installed during the latter half of the 1980s. Table 1 illustrates the process of the diffusion of STWs in the 
village, based on the synthesized information obtained from all the STW owners interviewed. It indicates how rapid the diffusion of STWs was during the period. By the beginning of the 1990s almost all the farmland in the village came to be covered under irrigation.

The mode of transaction of irrigation water started to change gradually from this period. Instead of renting out land to STW owners, farmers started to purchase water for a fixed amount of charge in cash per acre to grow boro paddy by themselves. It is estimated that at the end of the 1980s the number of cases of purchasing water exceeded that of seasonal land lease.

\section{4) Mid-1990s until today}

As the exploitation of groundwater accelerated, however, the groundwater level continued to decline and the water depletion problem became severer especially at the end of the irrigation season; i.e. March and April. Thus some STW owners were obliged to convert to SM. Table 1 shows that in the study village two SMs were first installed in 1992 and during 1995-97 another 7 SMs were introduced. The maximum technically irrigable area per unit of tubewell drastically increased from 40-50 bigha for electric STWs to 120 bigha for SMs, despite only a slight change in the horsepower of motors. However, the cropping pattern of aman-boro and their productivity experienced no substantial changes.

At the time of our survey in 2000, all the farmers purchased water either from DTWs, STWs, or SMs, paying a fixed amount of cash on a per acre basis. In other words, seasonal land lease by tubewell owners had completely disappeared. It was found that farmers do not want to rent out land any more even if tubewell owners desire it.

It seems that there are at least two reasons why the mode of transaction in the groundwater market changed completely. First, boro paddy cultivation technology became more and more popular and standardized, which made the choice between renting-out land and purchasing water indifferent and further gave farmers more incentives to cultivate by themselves so as to secure family labor income. Second, farmers became generally rich enough to cultivate boro paddy by themselves. In the old days they were too poor to afford necessary working capital for cultivation (and thus they
Table 2. Distribution of tubewells in the study village

\begin{tabular}{cccc}
\hline $\begin{array}{c}\text { Land ownership } \\
\text { (acre) }\end{array}$ & $\begin{array}{c}\text { Diesel } \\
\text { STW }\end{array}$ & $\begin{array}{c}\text { Electric } \\
\text { STW }\end{array}$ & SM \\
\hline 0 & & & \\
$0.01-1.49$ & 1 & 3 & \\
$1.50-2.49$ & 2 & 2 & 3 \\
$2.50-4.99$ & & 6 & 3 \\
$5.00-9.99$ & & 2 & 2 \\
$10.00-$ & 3 & 13 & 9 \\
Cooperative & & & \\
\hline Total & 2.72 & 6.54 & 7.00 \\
\hline $\begin{array}{l}\text { Average farm } \\
\text { size (acre) }\end{array}$ & & & \\
\hline
\end{tabular}

Source: Field survey in September 2000.

were obliged to choose just renting out land during the dry season), but such capital constraints gradually disappeared after the mid1980 s as the living standard of villagers improved after the 'Green Revolution'-induced agricultural and rural development."

\section{Economic Analysis of Shallow Tubewell Management}

In this section an economic analysis is attempted for private shallow tubewell management in the study village.

As mentioned earlier, at the time of the main survey in September 2000 there were in total 31 private shallow tubewells in the village, comprised of 3 diesel STWs, 18 electric STWs, and 10 SMs. However, it was found that out of these private tubewells, 5 electric STWs and one SM were owned and operated by the residents in other villages, who could not be included in the survey. Thus the sample size for the cost and return survey came down to twenty-five. Table 2 shows the farm size (in terms of ownership) distribution of the tubewell owners. Note here that 25 tubewells were owned and operated by 21 individual residents in the village, since two individuals each owned two electric STWs and one SM. In addition, the Gotera Village Cooperative Society ${ }^{8)}$ owned and operated one SM.

From Table 2 the tendency of a very skewed distribution of tubewells in favor of large farmers is evident. It is also clear that larger farm households tend to hold more electric 
Table 3. Cost and return of tubewell management

\begin{tabular}{|c|c|c|c|c|c|c|c|c|c|}
\hline & \multicolumn{2}{|c|}{ Diesel STW } & \multicolumn{4}{|c|}{ Electric STW } & \multicolumn{3}{|c|}{ SM } \\
\hline Sample size & \multicolumn{2}{|c|}{2} & \multicolumn{4}{|c|}{11} & \multicolumn{3}{|c|}{8} \\
\hline Initial investment (Rs.) & \multicolumn{2}{|c|}{12,500} & \multicolumn{4}{|c|}{13,158} & \multicolumn{3}{|c|}{56,388} \\
\hline Irrigated area (bigha) & $\begin{array}{c}2.5 \\
\text { (boro) }\end{array}$ & $\begin{array}{c}2.5 \\
\text { (veg.) }\end{array}$ & $\begin{array}{c}14.7 \\
\text { (boro) }\end{array}$ & $\begin{array}{c}7.7 \\
(a m a n)\end{array}$ & $\begin{array}{c}0.5 \\
\text { (aus) }\end{array}$ & $\begin{array}{c}0.9 \\
\text { (veg.) }\end{array}$ & $\begin{array}{c}32.5 \\
\text { (boro) }\end{array}$ & $\begin{array}{c}16.7 \\
(\text { aman })\end{array}$ & $\begin{array}{c}1.9 \\
\text { (veg.) }\end{array}$ \\
\hline Self-cultivated & 2.5 & 2.0 & 6.4 & 2.5 & 0.4 & 0.4 & 9.5 & 6.4 & 0.5 \\
\hline Water sales & 0 & 0.5 & 8.3 & 5.2 & 0.1 & 0.5 & 23.0 & 10.3 & 1.4 \\
\hline Water charge (Rs. /bigha) & 350 & 300 & 395 & 58 & 100 & 300 & 351 & 110 & 150 \\
\hline Gross revenue (Rs. /unit) & \multicolumn{2}{|c|}{1,625} & \multicolumn{4}{|c|}{6,130} & \multicolumn{3}{|c|}{13,375} \\
\hline \multicolumn{10}{|l|}{ Cost } \\
\hline Diesel/Electricity & \multicolumn{2}{|c|}{2,050} & \multicolumn{4}{|c|}{4,273} & \multicolumn{3}{|c|}{4,501} \\
\hline Repair & \multicolumn{2}{|c|}{750} & \multicolumn{4}{|c|}{1,280} & \multicolumn{3}{|c|}{1,759} \\
\hline Family labor & \multicolumn{2}{|c|}{860} & \multicolumn{4}{|c|}{2,845} & \multicolumn{3}{|c|}{2,588} \\
\hline Hired labor & \multicolumn{2}{|r|}{0} & \multicolumn{4}{|c|}{382} & \multicolumn{3}{|c|}{1,125} \\
\hline Total (Rs. /unit) & \multicolumn{2}{|c|}{3,660} & \multicolumn{4}{|c|}{8,780} & \multicolumn{3}{|c|}{9,973} \\
\hline Surplus (Rs. /unit) & \multicolumn{2}{|c|}{$-2,035$} & \multicolumn{4}{|c|}{$-2,650$} & \multicolumn{3}{|c|}{3,402} \\
\hline
\end{tabular}

Source: Field survey in September 2000.

STWs than diesel ones, and more SMs than electric STWs. No households with less than 1.5 acres of farmland possessed any kind of tubewell at all. It should be noted here that the distribution of operated farmland in Chakuda C. D. Block in $1990-91$ was as follows; $69.2 \%$ for less than 1 acre, $21.2 \%$ for $1-2$ acres, $8.1 \%$ for $2-$ 4 acres, $1.5 \%$ for $4-10$ acres, and $0.02 \%$ for 10 acres and more (Bureau of Applied Economics and Statistics [3]). Although we have no data on the distribution of land for all the households in the village it is evident that the distribution of STWs is highly skewed in favor of large farmers.

Table 3 summarizes the results of the cost and return analysis of shallow tubewell operations with average figures per unit of tubewell, shown separately for diesel STWs, electric STWs, and SMs. Gross revenue was calculated for each irrigated crop by multiplying the irrigated area (including self-cultivated area) by the unit price of water sales and then by summing them up. Regarding the cost, only operation and maintenance costs were estimated and incorporated; i.e. capital costs such as depreciation of machinery and capital interest were not included. Depreciation cost was not incorporated because of the old ages (and so the low historical prices) of most of the tubewells but it is estimated to be about Rs. 3,000 per year for SMs, which cannot be neglected. Interest for working capital was not incorporated because of the fact that a major portion of operational cost comprises family labor and electricity charge, which is not actually paid or can sometimes be paid later. Thus the estimated profit tends to be over-valued, but not to a large extent.

The figures for profit in Table 3 , although over-valued to some extent, are negative except for SMs. Such very low (and actually negative) returns to shallow tubewell investment become much clearer from the individual data shown in Fig. 1. Almost all the STWs brought about negative profit to the owners, and even in the case of SMs, only just half of them enjoyed positive profit.

It should also be noted that even in the case of the most profitable three SMs, the amount of profit per year ranges Rs. 10,000-15,000. When the depreciation cost of Rs. 3,000 mentioned above is deducted the rate of return to initial investment will be only $12-21 \%$. Thus it can be concluded that the argument of 'waterlords' is far from the reality in the study village. The skewed distribution of tubewells in favor of large (and relatively rich) farmers does not necessarily mean the monopolistic 


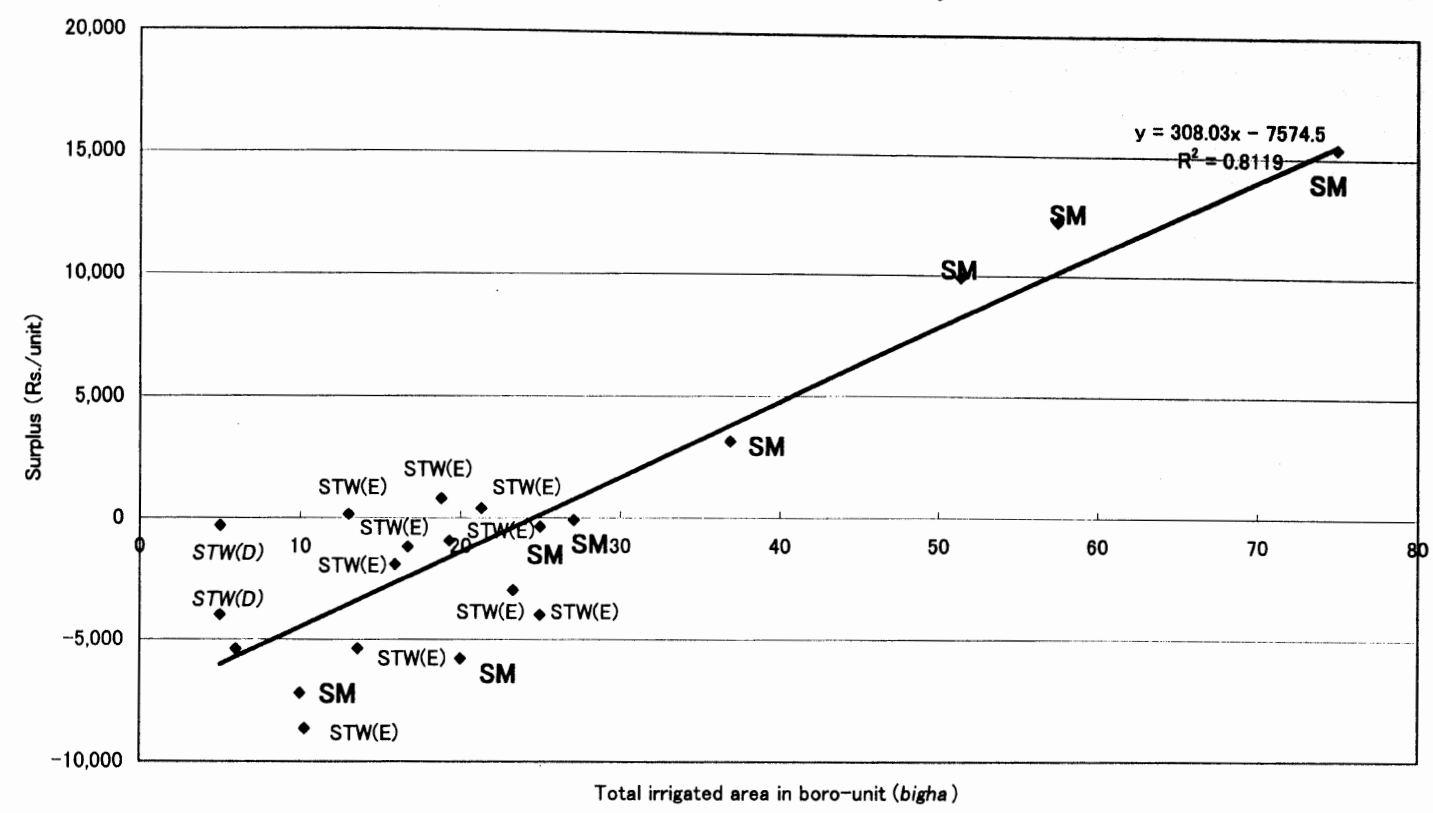

Figure 1. Profitability of tubewell investment in the study village

acquisition of agricultural profit by them, and actually the majority incurred a loss from the groundwater irrigation 'business'.

Why does the rate of return to shallow tubewell investment tend to be so low and even negative? From Fig. 1 it seems that the small command area was the major reason. It was found that all the STWs except for some SMs covered less than 25 bigha of borounit $^{9)}$ land under their irrigation, and the average command area in boro-unit actually achieved was 4.6 bigha ( $=1.5$ acres) for diesel STWs, 16.6 bigha (=5.5 acres) for electric STWs, and 38.5 bigha ( $=12.8$ acres $)$ for SMs respectively (Table 3 ). It can be judged from Fig. 1 that at least $25-30$ bigha ( $=8-10$ acres) is necessary for STW owners in order not to lose from their 'business'. Of course under the situation that all the non-SM STWs actually covered less than 25 bigha, the difference with SMs in terms of profitability can be attributed to the difference in irrigation technology. However, non-SM STWs can irrigate much larger areas than they do if there is no competition with surrounding tubewells and the additional cost for expanding command area is very small, considering the 'flat rate' system of electricity pricing adopted in West Bengal as in other parts of India as mentioned later in this paper, as well as the existence of scale- economy in the labor cost for irrigation. It should be remembered here that the maximum irrigable area is 40-50 bigha for STWs and 120 bigha for SMs. The low profitability is mainly attributable to such very a low capacity utilization.

Some background information can be given for such a low capacity utilization. First, the existing 3 diesel STWs installed in 1985, 1986, and 1993 can be characterized as 'marginal'. It is found from Table 1 that 8 out of 11 diesel STWs had already been electrified, and only 3 remained at the time of the survey. They were basically not for the sale of water, but for irrigating a small area for self-cultivation. The owners might not be able to purchase water from the surrounding electrified tubewells because their land was located on a relatively elevated area, and they were obliged to introduce and/or continue to depend on their own diesel STWs at a higher cost. Second, it was found that 4 out of 13 electric STWs could secure only a very small command area, due to either their 'marginal' nature similar to the diesel STWs mentioned above or due to competition with the neighboring SMs. But as was pointed out earlier, even the remaining 9 electric STWs could not cover sufficient command area due to the competition. Third, the same story can be applied to SMs; i.e. more than half of them 
Table 4. Cost and return of crop production in the study village

\begin{tabular}{|c|c|c|c|c|}
\hline & Aman & (share \%) & Boro & (share \%) \\
\hline Sample size & 9 & & 11 & \\
\hline Average cropped acreage & 5.9 & & 5.8 & \\
\hline Yield (maund/bigha) & 14.3 & & 15.9 & \\
\hline \multicolumn{5}{|l|}{ Gross revenue (Rs. /bigha) } \\
\hline Paddy & 2,951 & & 3,380 & \\
\hline Straw & 279 & & 250 & \\
\hline Total & 3,230 & 100 & 3,630 & 100 \\
\hline \multicolumn{5}{|l|}{ Cost (Rs. /bigha) } \\
\hline \multicolumn{5}{|l|}{ Current inputs } \\
\hline Seedling & 173 & & 206 & \\
\hline Urea & 93 & & 167 & \\
\hline TSP & 60 & & 122 & \\
\hline MP & 55 & & 69 & \\
\hline Other chemical fertilizers & 53 & & 50 & \\
\hline Manures & 0 & & 218 & \\
\hline Insecticides/Pesticides & 68 & & 69 & \\
\hline Sub-total & 502 & 15.5 & 901 & 24.8 \\
\hline \multicolumn{5}{|l|}{ Labor } \\
\hline Land preparation & 307 & & 314 & \\
\hline Transplanting & 190 & & 199 & \\
\hline Weeding & 277 & & 226 & \\
\hline Harvesting & 486 & & 553 & \\
\hline Others & 81 & & 81 & \\
\hline Sub-total & 1,341 & 41.5 & 1,373 & 37.8 \\
\hline \multicolumn{5}{|l|}{ Irrigation } \\
\hline Sub-total & 103 & 3.2 & 395 & 10.9 \\
\hline Total & 1,946 & 60.2 & 2,669 & 73.5 \\
\hline Surplus (Rs. /bigha) & 1,284 & 39.8 & 961 & 26.5 \\
\hline
\end{tabular}

Note: 1 maund $=37.3 \mathrm{~kg} ; 1$ bigha $=0.33$ acre.

Source: Field survey in September 2000.

could not get enough irrigated area.

In conclusion, it seems that at the time of our survey the groundwater market in the study village was in a process of adjustment, in which low-capacity STWs were being converted to high-capacity SMs and, therefore, under such a temporarily excessive competition in a 'transitional' period almost none the tubewells could earn enough profit from the water sales business.

Still at the same time, it should also be emphasized that even when the adjustment process is completed, most probably the water sales business will not become very profitable because of the harsh competition among the tubewell owners.

\section{Economic Analysis of Irrigated Farming}

Data on the cost and return of agricultural production were collected for major crops in the study village, although due to time constraints the survey was limited only to the shallow tubewell owners (cum-farmers). The results on aman and boro paddy production are summarized in Table 4 . Sample size was 9 and 11 respectively and the average figures are shown in the table.

The average yield of paddy in terms of 
maunds per bigha was 14.3 for aman and 15.9 for boro, which was equivalent to 3.95 tons and 4.40 tons per hectare respectively. Gross revenue was estimated by summing up the value of main product (paddy) with by-product (straw). Cost was estimated by classifying it into three components; i.e. current inputs, irrigation, and labor. The cost of seedlings was directly estimated from the market price since sales of seedlings were popular in and around the village and thus it includes some labor costs. Labor cost includes bullock labor and sometimes the cost of farm machinery such as power tillers. ${ }^{10)}$ Surplus was obtained by deducting the cost from the gross revenue.

It is evident from the table that compared to aman, boro cultivation requires much more current input (especially chemical fertilizers and manures) and irrigation, and therefore, higher cost per acre. On the other hand, not a large difference was observed between the two crops in the labor cost.

Theoretically, the surplus (Rs. 1,284 for aman and Rs. 961 for boro per bigha) should be equal to land rent under a well-functioning land rental market. The actual land rent in the village observed, on the other hand, was Rs. 1,0001,500 for aman and Rs. 1,000-1,200 for boro." Considering that the rice price was declining at the time of the survey due to the bumper harvest of rice in Bangladesh, ${ }^{12)}$ which put downward pressures on land rent for adjusting itself to the decreasing surplus, but with time lag, it can be concluded that the land rental market in the village was functioning rather well.

It is found from Table 4 that in the boro paddy cultivation the share of irrigation cost to gross revenue was only $11 \%$ on average, which may not put much financial burden on water buyers. This point can be more clearly understood from the following two different viewpoints.

First is a historical point of view. In the study village, as mentioned above, seasonal land lease by tubewell owners has long been the major mode of groundwater transaction and the land rent was 3 maunds of paddy per bigha. Considering that the average yield of boro was a little bit higher at that time (about 18 maunds), the share of land rent to gross revenue was only about $15 \%$, much lower than the $27 \%$ shown in Table 4 . The difference is as much as $12 \%$. Under the simplest assumption, the share of implicit irrigation charge to gross revenue at earlier days can be estimated at about $23 \%$ ( $11 \%$ at present plus $12 \%$ ). Tubewell owners might have been enjoying a large amount of profit from their business, through rent land from farmers paying a low price to. ${ }^{13)}$ However, as more tubewells were introduced, the groundwater market in the village became more and more competitive, resulting in the continued decline of real water charges.

Second is the comparison with a Bangladesh case study conducted by the same author. Table 5 summarizes the results of the cost and return survey of aman and boro paddy production in a study village in Bogra district, Bangladesh in December 1999 (Fujita [8]). Irrigation by STWs also prevailed in the village, although the majority were diesel-operated. It was found that the share of irrigation cost in gross revenue for boro cultivation was $13 \%$, only a little bit higher than $11 \%$ in Gotera village.

Another surprising point that Table 5 indicates is that the factor share of labor in rice production is much higher in West Bengal $(38-42 \%)$ than in Bangladesh (20-30\%) and vice versa for that of land (27-40\% in West Bengal vs. $49-58 \%$ in Bangladesh). ${ }^{14)}$ It means that the irrigated agriculture developed in West Bengal is more equitable in favor of landless laborers compared to that in Bangladesh.

The large difference in labor share between the two regions cannot be explained only by the difference in agricultural wage rate. The agricultural wage rate in West Bengal was Rs. $40-45$, only about $35 \%$ higher than in Bangladesh, where the wage rate was Tk. 40, equivalent to Rs. 33 at the market exchange rate. There is a strong possibility that the production of rice, especially boro in West Bengal, is much more labor-intensive than in Bangladesh but the reasons why remain unclear. ${ }^{15)}$ It remains as one important part of the future research agenda.

\section{Structure of Groundwater Market}

Finally, let us discuss factors affecting the structure of the groundwater market in the study village. We first discuss the issue of state-operated DTWs, followed by the impact of power subsidy to the minor irrigation 
Table 5. Cost and return of crop production in a Bangladesh village

\begin{tabular}{|c|c|c|c|c|}
\hline & Aman & (share \%) & Boro & (share \%) \\
\hline Sample size & 7 & & 8 & \\
\hline Average cropped acreage & 4.6 & & 4.4 & \\
\hline Yield (maund/bigha) & 11.7 & & 16.2 & \\
\hline \multicolumn{5}{|l|}{ Gross revenue (Tk./bigha) } \\
\hline Paddy & 3,122 & & 4,049 & \\
\hline Straw & 393 & & 256 & \\
\hline Total & 3,515 & 100 & 4,305 & 100 \\
\hline \multicolumn{5}{|l|}{$\begin{array}{l}\text { Cost (Tk. /bigha) } \\
\text { Current Inputs }\end{array}$} \\
\hline Seed & 61 & & 96 & \\
\hline Fertilizer & 250 & & 477 & \\
\hline Insecticides/Pesticides & 0 & & 22 & \\
\hline Sub-total & 311 & 8.8 & 595 & 13.8 \\
\hline Labor & 684 & & 717 & \\
\hline Capital rental & 355 & & 131 & \\
\hline Irrigation & 1,039 & 29.6 & 848 & 19.7 \\
\hline Capital interest & 0 & 0 & 546 & 12.7 \\
\hline Sub-total & 135 & 3.8 & 199 & 1.0 \\
\hline Total & 1,485 & 42.2 & 2,188 & 50.8 \\
\hline Surplus (Tk. /bigha) & 2,030 & 57.8 & 2,117 & 49.2 \\
\hline
\end{tabular}

Note: 1 maund $=37.3 \mathrm{~kg} ; 1$ bigha $=0.33$ acre.

Source: Field survey in Titkhur village, Bogra district, Bangladesh in December 1999.

sector. Lastly several characteristics of the groundwater market are discussed in relation to the economic behaviors of shallow tubewell owners and water buyers.

\section{1) State-operated DTWs}

As mentioned earlier, state-operated DTWs have a distinct boundary with their network of underground pipes. There are two enclaves in the village formed by the DTWs, where farmers have been enjoying subsidized irrigation water from the State Government for more than 35 years. The subsidized water charge in the year 2000 was Rs. 80 per bigha for boro and Rs. 20-25 for aman, while the market rate was Rs. $350-400$ and Rs. 100 , respectively. Officially it is not necessary for the beneficiary farmers to incur any other costs, but actually because of the complete 'idleness' of the official operator and the assistants, they are obliged to employ another operator on a seasonal basis and share the burden of his wage equally (based on irrigated acreage) among them. The salaries paid to the official operator and assistants are far from negligible and so it can be pointed out that not-a-small portion of subsidies to the minor irrigation sector in West Bengal are thus completely wasted.

Another critical problem for the stateoperated DTWs is that they are approaching the end of their expected life. The installation year of the DTWs in the village was 1964 and more than 35 years have already passed, during which no major rehabilitation was done. At the time of the survey there was no symptom of any functional disorder, but it was expected that the 'time' would come in the near future. What will happen at that time? Let us examine the case of a nearby village in the neighboring Haringhata C. D. Block, Nadia district. 
The name of the village is Birohi, and it is located on the way from Kalyani town to Gotera village. The DTW of the village was also 35 years old and to lift sufficient water became more and more difficult during recent years. In 1999 the re-excavation of tubewell and an exchange of motors was implemented, the total cost of which was about Rs. 475,000 , although farmers did not know the exact figure. The other facilities such as the network of underground pipes continued to be utilized. Farmers should repay the expenses in the coming seven years, with two years' grace period, and $16 \%$ interest will be imposed. In addition, all the operation and maintenance costs, including the operator's salary, electricity charges, etc., will be borne by the farmers.

In short, the State Government's intention is to transfer rehabilitated DTWs to a group of beneficiaries and let them manage them. The new water charge agreed to by the beneficiaries in Birohi village was Rs. 500 for boro, Rs. 60 for aman, and so forth, almost same as that of the private shallow tubewells in the same village. Still one of the farmers' leaders could not conceal his anxiety whether they could repay the debt and continue to operate the DTW successfully. It seemed that one could not be so optimistic about the future of a large number of old state DTWs in West Bengal.

\section{2) Power subsidy to minor irrigation}

Next, let us discuss the issue of power subsidy. The West Bengal Government, just like the other states in India, has been providing huge amounts of power subsidy to agriculture, especially to the minor irrigation sector. The subsidy has been given not only through the lower tariff charged for tubewells, but also through the special tariff system called 'flat rate'. Under this system tubewell owners should only pay a fixed amount of money according to the motor's horsepower, and thus the marginal cost for pumping water is minimized, enabling tubewell owners to exploit groundwater excessively. But as Shah argued, it is plausible that the cheaper marginal cost (due to adopting the 'flat rate' system) can lower the market water charge on the other hand, and thereby benefit water buyers (Shah [16]).

The State Government announced a revision of the power tariff rate in December 1998, effective from January 1999. It was after more than seven years after the last revision in October 1991. Major revisions related to minor irrigation sector were as follows:

a) For STWs with 3-5 horsepower, the 'flat rate' system was maintained, but the rate was raised substantially. There was no distinction between STWs and SMs before, but a new tariff was set for SMs at a $50 \%$ higher level than the conventional STWs. In sum, the tariff was raised from Rs. 1,700 to Rs. 3,284 for non-SM STWs and Rs.4,932 for SMs, which means 93\% and $190 \%$ rises respectively.

b) For DTWs and RLIs (river lift pump irrigation), the per KWh tariff rate (a 'flat rate' system was never adopted) was raised from Rs. 55 to Rs. 123 , with a rise of $124 \%$.

There are several critical points to be discussed here.

First, with the revision in December 1998 the power tariff was raised to a large extent nominally, but to a much lesser extent in real terms, if the high inflation of about 95\% during 1991-98 (Wholesale Price Index in Kolkata) is considered. It is found that only for SMs was tariff substantially raised in real terms too, but actually most of the SMs are registered as conventional STWs, for which a much lower rate is being applied. Such a large-scale manipulation ${ }^{16)}$ seems to be reflected in a negligible difference in the electricity cost between electric STWs and SMs in the study village (Table 3). It can be concluded that the State Government could not succeed in withdrawing power subsidies from agriculture, at least to a large extent.

Second, considering the fact that almost none the private shallow tubewells in the village could earn enough profit, it is almost evident that the benefit of the power subsidy 'trickled down' to water buyers sufficiently.

\section{3) Efficacy of groundwater market}

As discussed earlier, it seems that at the time of the survey the groundwater market in the village was under a kind of adjustment process, in which low-capacity STWs were being switched to high-capacity SMs. As Fig. 2 shows, in the process of conversion of STWs to SMs, however, some congested areas appeared, where total capacity of irrigation exceeded the actual area to a large extent, resulting in a suspension of operation by some conventional STW owners. It seems it will take some time (probably a rather prolonged period, consider- 


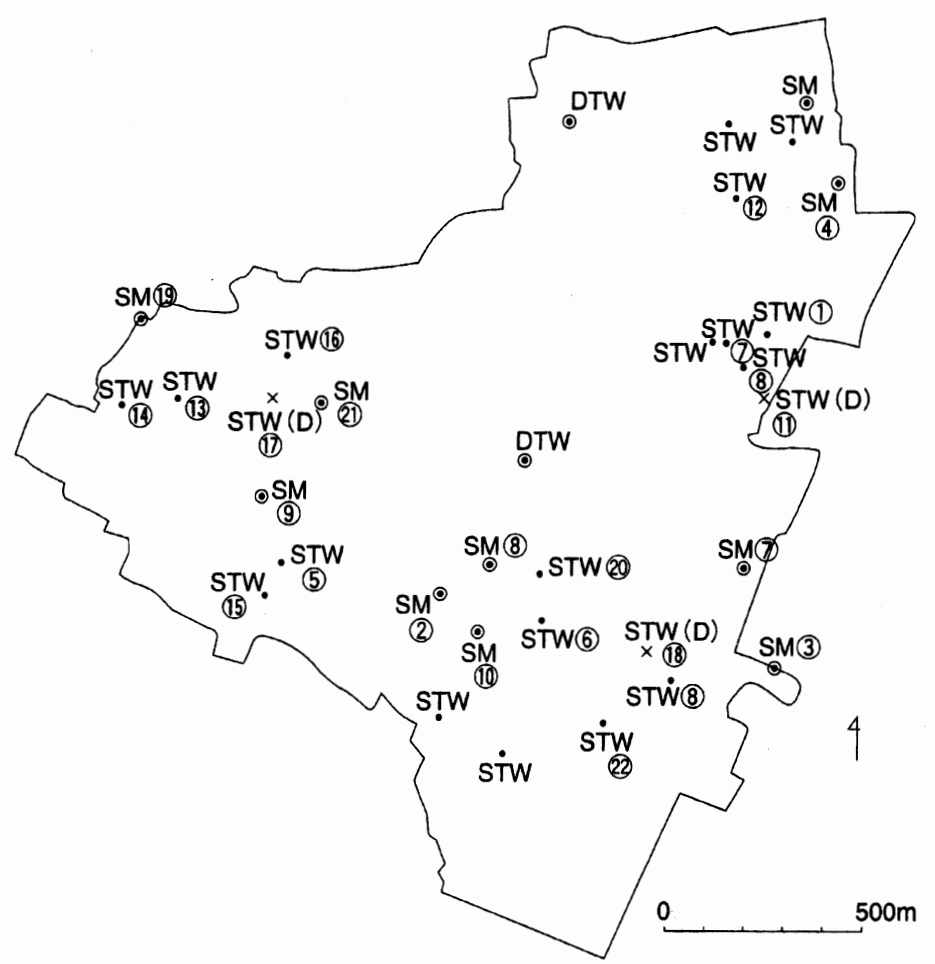

Figure 2. Location of tubewells in the study village

Source: Prepared by the authors.

ing that nobody is trying to take initiative for necessary coordination as is usual in rural India) until this adjustment process is completed, during which tubewell owners will continue to suffer financial losses due to low capacity utilization.

It should also be pointed out that the conversion from STWs to SMs is not a fundamental solution to the problem of declining groundwater level. The mere exploitation of deeper groundwater by introducing new machinery is widely observed in other parts of India including Punjab, about which experts have repeatedly raised alarms. It is clear that not only did the market mechanism fail to solve the problem, but the public sector also failed so far to find effective measures.

Another problem observed in the village was that some water buyers, especially those who cultivate low-elevated land, are reluctant to pay water charges. Irrigation water can be made to flow into their land 'automatically' because of the topographic condition, and thereby they can insist to tubewell owners that they did not ask them to provide water, while actually benefiting from the irrigation scheme. This problem becomes more persistent in all types of land in aman season when the need for irrigation depends on the weather conditions. Such a morally hazardous behavior of water buyers ${ }^{17)}$ puts serious financial pressure on the water sales business, even within a rural community like our study village that could establish and manage an excellent cooperative society. ${ }^{18)}$

\section{Conclusions}

The major findings and their implications of this article are as follow:

First, at least in the study village, the engine of agricultural development since the 1980s was found to be the rapid diffusion of private shallow tubewells invested in by large farmers, without any direct relation to the agrarian reforms such as redistribution of land, registration of sharecroppers (Operation Barga), and/or strengthening of local government bodies. The contribution of agrarian reforms, if any, should be argued by exploring their indirect impacts on the irrigation-led agricultural 
development. ${ }^{19)}$ For example, the rural electrification during the 1980 s in West Bengal, an important factor that promoted the dissemination of electrified tubewells, might be to some extent connected with the strengthened local government bodies.

Second, it was found that the distribution of tubewells was highly skewed in favor of large farmers in the study village, the same as in other studies, but it does not automatically follow that tubewell owners monopolize relatively high returns to boro paddy cultivation. On the contrary, our study shows that the water sales business became less and less profitable, as more tubewells were introduced in a confined area. Real water charges declined to a large extent, with the changes in the dominant mode of water transaction from the seasonal land lease by tubewell owners to the purchase of water by farmers. In a word, water buyers, not tubewell owners, benefited more from the 'Green Revolution' in the dry season, at least after the groundwater market become competitive. The argument of 'waterlords' is questionable in the present rural West Bengal situation, the same as in present-day rural Bangladesh (Fujita [8]).

Third, in the West Bengal study village, it was found that the factor share of land in rice production is much smaller (and the share of labor much larger) than in a Bangladesh village in Bogra district. Therefore, it can be said that rural laborers also benefited from the irrigation-led agricultural development, especially when compared to the Bangladesh case, although the reasons remain to be explored more in the future in a systematic manner. ${ }^{20)}$

Fourth, power subsidy to the minor irrigation sector in West Bengal seems to show no sign of being reduced in spite of the revision of power tariff in December 1998, but it should be noted at the same time that the benefit of the subsidy is being sufficiently 'trickled down' to water buyers, instead of being monopolized by tubewell owners.

Fifth, a sound socio-economic study is urgently needed to assess the new policy of West Bengal State Government by which stateoperated DTWs are gradually transferred to farmers' groups after their major rehabilitation.

Sixth, the problem of declining groundwater level should be tackled more seriously as the conversion of STWs to SMs is not a fundamental solution. At the same time, some appropriate institutional support should be given to lessen the transaction costs that will inevitably be borne in the process of the adjustment, under which STWs are shifted to SMs.

1) According to the official statistics the average annual growth rate of foodgrain production in the 1980 s was as follows: $6.5 \%$ in West Bengal, $3.8 \%$ in Bihar, 2.7\% in Assam, 4.1\% in Orissa, compared to $4.0 \%$ in Punjab, $4.3 \%$ in Haryana, $3.8 \%$ in Himachal Pradesh, 3.5\% in Uttar Pradesh, $0.9 \%$ in Andhra Pradesh, $0.5 \%$ in Karnataka, 2.9\% in Tamil Nadu, $-2.1 \%$ in Kerala, $1.2 \%$ in Maharashtra, $-1.9 \%$ in Gujarat, and $0.9 \%$ in Rajasthan. Note here that in western and southern India, where coarse grains are the staple cereals, crops other than foodgrains such as oilseeds and fruits registered a high growth rate and contributed to overall agricultural development. On the other hand, the average annual growth rate of various crop productions in India in the $1980 \mathrm{~s}$ was as follows: $4.3 \%$ for wheat, $4.1 \%$ for rice, $3.9 \%$ for maize, $2.4 \%$ for pulses, $6.1 \%$ for oilseeds, $4.4 \%$ for sugarcane, and $3.2 \%$ for cotton.

2) Most of the articles contained in Rogaly, HarrisWhite and Bose [14] reflect this basic tone of crediting rapid agricultural growth to the agrarian reforms. Needless to say, the argument of the Left Front government of West Bengal lies along the same lines, as reflected in the writings of annual Economic Review. An example is as follows: This achievement in the agricultural sector is largely due to the development strategy followed in the State. The corner-stone of the strategy is the effective implementation of land reform measures. Next, the strategy involves the mobilization of the resources of the State to provide crucial non-land inputs like seeds, fertilizers, irrigation and credit to the beneficiaries of land reform measures as well as other small and marginal farmers. This allows the beneficiaries of land reform measures as well as other poor farmers to take up productive activities. Thus the strategy is crucially dependent on the productive activities of the small farmers for agricultural growth. And since per acre production as well as labour absorption is higher in the small farms of the poor working farmers, the strategy leads to the maximization of output and employment. The strategy is effectively operationalised through the decentralised district level planning process, in which the rural poor through the Panchayats play a decisive role (Government of West Bengal [10], p. 20).

3) Although the latest article of Banerjee, et al. [1] built an elaborate economic model and it looks 
likely to succeed in proving the hypothesis that the land reform measures did significantly contribute to agricultural growth by empirical data persuasively, it also includes serious problems; i.e. they totally ignored the critical role played by the private tubewell irrigation development in the agricultural growth in the period. They selected the average rice yield regardless of aus, aman, and boro as a key independent variable, and in the explanatory variables they did not include any variable relating to the private irrigation development due to (probably) the lack of data. If regions with rapid private irrigation development (and thus rapidly expanding boro cropped area, which raises average rice yield) happen to coincide with the regions where Operation Barga was more successfully conducted, the result is that they fail to separate the effects of private irrigation development from those of Operation Barga.

4) Webster reported that the tubewell owners in his study village refused to sell the water and instead rented land on a fixed contract (fixed rent seasonal tenancy) called 'thika', which seems to be the major reason why he concluded that the high returns to boro paddy cultivation are secured by the owners. However, he also reported that by 1991 there were approximately forty operating tubewells within the village mauza, which seems to be a sufficient number to 'compete' with each other, so that it is more appropriate to analyze the boro cultivation profitability under the prevailing land rent, before reaching his rather strong conclusion.

5) There are several pioneering studies conducted in other parts of India. See Janakarajan [11] in Tamil Nadu, Pant [13] in Uttar Pradesh, Shah [16] in Gujarat, Kahnert and Levine [12] in several parts of the Gangetic basin, and Shah and Ballabh [17] in Bihar. See also some case studies in Bangladesh by one of the authors (Fujita and Hossain [7], Fujita [8]).

6) Note that the introduction of DTWs started in West Bengal at the beginning of the 1950s, long before the era of the 'Green Revolution'. See Chowdhury [4].

7) According to the study on the Gotera Village Cooperative Society by Suda [18], the financial position of the Society experienced an impressive improvement since the late $1980 \mathrm{~s}$, mainly because the programme of saving mobilization was successful. The success of saving mobilization itself indicates the rising living standard of the villagers.

8) In August 1998, the number of cooperative members was 714 and 7 permanent staff were working for various activities including credit (saving mobilization and loan disbursement), sales of fertilizer, multiplication \& distribution of improved seeds for paddy, and irrigation.
9) Irrigated area was aggregated for all irrigated crops, using the water charge $($ boro $=100)$ as a weight.

10) Labor cost is estimated operation-wise and type of labor (family, exchange, or hired)-wise. Farmers utilized either power tiller or bullock for land preparation, the cost of which is included in the labor cost in Table 4 so that the table is comparable with Table 5 . When family production factors are used the cost is evaluated by their rental rate or the hired wage rate.

11) The major contractual arrangements of tenancy in the study village were lease contract, in which a fixed amount of cash is paid in advance for a season of aman or boro production. Sharecropping was not practiced so far as the authors know. According to Table 4 the factor share of land for paddy production in a year is $33 \%$ on average, which indicates that under the Operation Barga if the share accrued to sharecroppers and landowners is actually $50 \%$ each as reported in Banerjee, et al. [1] it turns out that sharecroppers will lose in the study village. This may be one of the reasons why we did not hear about sharecropping and Operation Barga in the village. Note at the same time, however, that the share accrued to landowners is regulated at no more than $25 \%$ under the West Bengal Land Reforms Act, 1955.

12) A prolonged and severe flood attacked Bangladesh in 1998. After that a large volume of rice was exported from West Bengal to Bangladesh (Dorosh [6]), which resulted in a substantial rice price hike in West Bengal. But in the following year of 1999 Bangladesh enjoyed a bumper harvest and stopped rice imports; thus rice prices started to decline in West Bengal.

13) See a case study in Bangladesh by one of the authors (Fujita and Hossain [7]), where the same type of seasonal land lease by tubewell owners called Chaunia was widely observed and analyzed. According to their analysis, however, even under the Chaunia system tubewell owners did not enjoy exorbitant profit, if the high interest rate in the rural informal credit market is taken into account. This argument is closely related to how to interpret the argument of Webster [19] mentioned in Note 4 ), but he did not conduct any economic analysis anyway.

14) The different methodology and the categorization adopted in labor cost estimate in the Bangladesh village with the West Bengal counterpart is problematic, especially considering that in Bangladesh family labor cost is under-estimated. However, if the fact that the surplus (gross revenue minus production cost including labor cost) was more or less equivalent to the actual land rent in the Bangladesh case (Fujita [8]) is taken into consideration, the estimated labor cost cannot be very 
far from the 'real' one. The large difference in factor shares in paddy production does exist.

15) The over-estimation of labor hours in West Bengal may be one of the possible reasons, because piece rate labor contracts are more popular in West Bengal than in Bangladesh (private communication with Dr. Bhaswar Moitra, Reader, Economics Department, Jadavpur University, Kolkata). However, even if this is the case, it explains only a part of the difference.

16) There is a possibility that farmers did not manipulate. SMs require permission from the State Water Investigation Department but actually it is quite difficult in many areas (private communication with Bhaswar Moitra, Reader, Economics Department, Jadavpur University, Kolkata).

17) The problem of moral hazard in both water sellers and buyers is much more serious in Bangladesh. See Fujita [8].

18) On the good performance of the cooperative society in the village, see Suda [18].

19) Gazdar and Sengupta submitted an interesting hypothesis that the investment in tubewells accelerated only when uncertainties about land tenure disappeared after a thorough implementation of land reforms by the Left Front State Government (Gazdar and Sengupta [9]). It seems to the author that this is possible but so far evidence to support it is lacking.

20) The same argument on the difference between West Bengal and Bangladesh has already been presented by Dasgupta [5], but further discussions with more solid economic data are required.

\section{References}

[1] Banerjee, A. V., P. J. Gertler and M. Ghatak. "Empowerment and Efficiency: Tenancy Reform in West Bengal," Journal of Political Economy, Vol. 110, No. 2, 2002, pp. 239-280.

[2] Boyce, J. K. Agrarian Impasse in Bengal: Institutional Constraints to Technological Change, Oxford: Oxford University Press, 1987.

[3] Bureau of Applied Economics and Statistics, Government of West Bengal. District Statistical Handbook Nadia 1996 \& 1997 (combined).

[4] Chowdhury, B. K. Economics of Tubewell Irrigation in West Bengal, Santiniketan: Agro-Economic Research Center, 1971.

[5] Dasgupta, A. Growth with Equity: The New Technology and Agrarian Change in Bengal, Dhaka: The University Press Ltd., 1998.

[6] Dorosh, P. A. "Trade Liberalization and $\mathrm{Na}$ tional Food Security: Rice Trade between Bangladesh and India," World Development, Vol. 29, No. 4, 2001, pp. 673-689.

[7] Fujita, K. and F. Hossain. "Role of the Groundwater Market in Agricultural Development and Income Distribution in Bangladesh: A
Case of a Village in Bogra District," The Developing Economies, Vol. 33, No. 4, 1996, pp. 442-463.

[8] Fujita, K. "1990 Nendai Banguradesyu niokeru Chikasui Sijyo no Henyo: Hikouritsu no Kozo to Syotoku Bunpai eno Ganni (Transformation of Groundwater Market in Bangladesh in the 1990s: Inefficiency of Market and Implications to Income Distribution)," Ajia Keizai (Monthly Journal of Institute of Developing Economies), Vol. 42, No. 6, June 2001, pp. 26-53.

[9] Gazdar, H. and S. Sengupta. "Agricultural Growth and Recent Trends in Well-Being in Rural West Bengal," in Rogaly, Harris-White and Bose [14], pp. 60-91.

[10] Government of West Bengal. Economic Review, 1999-2000.

[11] Janakarajan, S. "Interlinked Transactions and the Market for Water in the Agrarian Economy of a Tamilnadu Village," in S. Subramanian, ed., Themes in Development Economics: Essays in Honour of Malcolm Adiseshiah, New Delhi: Oxford University Press, 1992.

[12] Kahnert, F. and G. Levine, ed., Groundwater Irrigation and the Rural Poor: Options for Development in the Gangetic Basin, A World Bank Symposium, World Bank, 1993.

[13] Pant, N. New Trend in Indian Irrigation: Commercialisation of Ground Water, New Delhi: Ashish Publishing House, 1992.

[14] Rogaly, B., B. Harriss-White and S. Bose, ed., Sonar Bangla?: Agricultural Growth and Agrarian Change in West Bengal and Bangladesh, Dhaka: The University Press Ltd., 1999.

[15] Saha, A. and M. Swaminathan. "Agricultural Growth in West Bengal in the 1980s: A Disaggregation by Districts and Crops," Economic and Political Weekly, Vol. XXIX, No. 13, March 26, 1994.

[16] Shah, T. Groundwater Markets and Irrigation Development: Political Economy and Practical Policy, Oxford: Oxford University Press, 1993.

[17] Shah, T. and V. Ballabh. "Water Markets in North Bihar: Six Village Studies in Muzaffarpur District," Economic and Political Weekly, Vol. XXXII, No. 52, 1997-1998, pp. A-183-A190.

[18] Suda, T. "Indo no Sinyou Noukyo Kaikaku: Nishi Bengaru Syuu Ichi Yuryou Noukyo no Jirei karano Kousatsu (Reforms of Agricultural Credit Cooperatives in India: A Case Study of a Primary Agricultural Credit Society (PACS) in West Bengal," Ajia Keizai (Monthly Journal of Institute of Developing Institute), Vol. 43, No. 12, pp. 2-29.

[19] Webster, N. "Institutions, Actors, and Strategies in West Bengal's Rural Development-A Study on Irrigation," in Rogaly, Harris-White and Bose [14], pp. 329-356.

(Received October 25, 2002; accepted February 17, 2003) 